Journal of Planning Literature. 1987, vol. 2, no. 1. p. 7-24.

ISSN: 0885-4122 (print) 1552-6593 (online)

DOI: $10.1177 / 088541228700200102$

http://intl-jpl.sagepub.com/

http://jpl.sagepub.com/content/by/year

http://jpl.sagepub.com/content/2/1.toc

(C) 1987 The Ohio State University Press.

\title{
Reference Sources in City Planning in the United States
}

\begin{abstract}
Jane McMaster
An extensive, cross-disciplinary literature has developed in city planning since its emergence as a profession over seventy years ago. This article surveys reference sources that serve as access points to the literature on the physical aspects of city planning in the United States. Comprehensive bibliographies, historical and biographical works, and the publications of professional organizations are covered in the context of the historical development of this literature. Currently available city planning research took and sources for the special topics of cities, housing, and historic preservation are also discussed.
\end{abstract}

City planning is a relatively new profession in the United States. It emerged approximately seventy years ago as a synthesis of several disciplines, chiefly architecture, landscape architecture, law, and civil engineering. It has also incorporated elements of various social reform movements. The cross-disciplinary roots of city planning, as well as the extensive literature related to the field, call for the researcher to be aware of the many reference sources that can serve as crucial access points for effective and efficient research.

This article surveys reference sources on city planning in the United States. The sources discussed have been selected in accordance with the traditional concept of city planning as physical planning. Sources which deal with the social, environmental, political, and economic aspects of city planning are a topic for another article.

The article first discusses the historical development of literature on city planning, concentrating on comprehensive bibliographies, historical and biographical works, and literature published by professional organizations. The article then discusses currently available city planning research tools, emphasizing comprehensive sources that have been organized by type: library collections, indexes and abstracts, on-line databases, encyclopedias and dictionaries. The third section of the article discusses sources related to the special topics of cities, housing, and historic preservation. The article concludes with a brief general evaluation of reference sources in city planning and a prospectus for the future of this literature.

\section{HISTORICAL DEVELOPMENT OF PLANNING LITERATURE REFERENCES}

\section{Comprehensive Bibliographies}

The development of comprehensive city planning bibliographies is easily traced, not only because the field is relatively new but also because of Theodora Kimball Hubbard, librarian at Harvard University's School of Landscape Architecture from 1911 to $1924 .{ }^{1}$ With Harvard faculty member James S. Pray, she created the first classification scheme for literature of the profession, published in 1913 as City Planning; A Comprehensive Analysis. ${ }^{2}$ In 1915, the National Conference on City Planning published Hubbard's first bibliography, Classified 
Selected List of References on City Planning, which followed the classification she had earlier developed. In 1923 her Manual of Information on City Planning and Zoning was published, providing thorough coverage of the subject from the turn of the century to 1923. The major portion of the book was devoted to the classified list of material on city planning, which could be accessed by topic and through a subject index. But Hubbard also included information on the National Conference on City Planning, recommended books for a city planning library, listed American periodicals devoting space to city planning, and compiled a short list of typical American city planning reports. (These three works were published under Hubbard's maiden name, Theodora Kimball.)

Hubbard and Katherine NcNamara, the new librarian for the Harvard School of Landscape Architecture, issued a supplement to the Manual, called Planning Information Up-toDate, in 1928. The classification scheme was continued with new references filling the gap between 1923 and 1928, and a comprehensive author index for both publications was included. In 1936, McNamara published another supplement called Bibliography of Planning, 1928-1935. Dedicated to the memory of Theodora Kimball Hubbard, the second supplement follows the format of the two earlier books and contains an author and subject index for the material covered.

Samuel Spielvogel provided the next comprehensive bibliography of American city planning in 1951. Spielvogel was then director of the New Haven Redevelopment Agency, but most of the work on this bibliography was completed between 1946 and 1948 while he was a student at Yale University. Titled A Selected Bibliography on City and Regional Planning, the book picks up where McNamara left off in 1936. Regrettably, Spielvogel did not continue Hubbard's classification scheme, but he did list individual topics under the broad categories of history, legislation, social considerations, transportation, technical problems, economics, theory, visual techniques, regionalism, and major projects. This work is international in scope and covers both books and articles. Most entries are annotated. Separate lists of directories, periodicals, textbooks, and selected planning reports are included along with subject and author indexes, which makes this reference a very useful tool for analysis of what was happening in the field of planning in the 1930s and 1940s.

The next general bibliographic effort was undertaken by George Bestor, a civil engineer who felt he needed more city planning background information in his work. He began by preparing a reading list in 1956 for his own use, but each succeeding edition became more comprehensive. Bestor credits Holway R.Jones, then librarian at the University of Oregon, with being largely responsible for the most recent edition, published in 1972 as City Planning Bibliography; A Basic Bibliography of Sources and Trends. This source contains very detailed annotated citations for books only. The three major headings are: the nature and form of cities, history of cities and city planning, and contemporary comprehensive city planning, each of which is further subdivided into specific topics. In addition, pertinent directories, periodical lists, abstracting services, and professional organizations are included along with excellent subject and author indexes.

Two other well-known academics have contributed important bibliographies to the field of city planning. Melville C. Branch, faculty member at the University of Southern California, has, over the past forty years, written several important books and compiled many bibliographies related to planning. His most extensive bibliographic work is Comprehensive Urban Planning; A Selective Annotated Bibliography with Related Materials (1970). This book is oriented toward the theoretical basis for planning and places less emphasis on its historical origins. Unlike 
Bestor, Branch includes journal articles. The broad subjects of process, theory, methodology, and institutionalization, among others, are subdivided not only by topic but also by type of publication, such as books, reports, pamphlets, and articles. Each entry is annotated. As several of the previous authors mentioned did, Branch provides lists of related material, including planning agencies, publishers, and colleges and universities, along with complete indexing by subject, author, and title.

The other prominent scholar to have contributed a noteworthy comprehensive bibliography is F. Stuart Chapin, Jr., longtime faculty member at the University of North Carolina at Chapel Hill. Best known for his text Urban Land Use Planning, he originated this bibliography as a source of background reading for the classes he taught. The last edition of Selected References on Urban Planning Concepts and Methods, published in 1978, is an inclusive listing of material for the 1960s and 1970s arranged by such categories as systems approaches, the urban economy, population studies, planning for residential areas, school plant planning, urban transportation planning, urban land-use planning, planning for industrial and commercial areas, evaluation, and citizen participation. Although the lack of annotations or indexes limits access to the material covered, Chapin has done such a good job in outlining particular subjects and in organizing the bibliography that it is worth the extra time to review this source.

One of the more recent developments in comprehensive bibliographies for city planning is the Gale Research Company series of Urban Information Guides edited by Thomas Murphy. The title in this series which is broadest in scope is Urban Planning; A Guide to Information Sources (1979) prepared by Ernest Alexander, Anthony Catanese, and David Sawicki, all then at the Department of Urban Planning at the University of Wisconsin. The entries, most of which are annotated, are arranged under the general chapters History and Development of Planning, Theory and Context of Planning, and Methods and Techniques, which are further subdivided by topic. Author, title, and subject indexes are provided along with other related references and a list of relevant journals. Other titles in this series that follow the same formula but have a narrower, more specialized focus are Joseph Zikmund's Suburbia: A Guide to Information Sources (1979), Anthony Filipovitch's Urban Community: A Guide to Information Sources (1978), Mark Drucker's Urban Decision-Making: A Guide to Information Sources (1981), John Rouse's Urban Housing: Public and Private: A Guide to Information Sources (1978), Thomas Murphy's Urban Indicators: A Guide to Information Sources (1980) and Urban Law: A Guide to Information Sources (1980), Bernard Ross's Urban Management: A Guide to Information Sources (1979), and Dennis Palumbo's Urban Policy: A Guide to Information Sources (1979).

The bibliographies mentioned so far document the development of city planning literature. The early titles provide especially good access to primary research material in the field. But researchers pursuing historical inquiries will also be aided by histories of planning, biographical reference sources, and literature published by professional planning organizations. These are discussed below.

\section{Planning Histories and Biographies}

Interest in the history of city planning was spurred by the fiftieth anniversary of the American Institute of Planners (AIP), founded as the American City Planning Institute in $1917 .{ }^{3}$ Russell VanNest Black, chairman of the committee commemorating the event, wrote Planning and the Planning Profession; The Past Fifty Years, 1917-1967, describing the founding of city 
planning in this country. The book also includes sketches of twenty-two of the fifty-two charter members of the organization and short blurbs on its Distinguished Services Award winners. At this same time, Mel Scott, University of California at Berkeley faculty member, was commissioned by the AIP to write a history of the profession which he titled American City Planning Since 1890. Published in 1969, this monumental survey provides a thorough chronicle, by decade, of each phase of planning in the U.S. Although not a critical history, Scott's exhaustive text, extensive indexing, and bibliographies furnish excellent access to a great deal of information on people and events in this country's planning history.

In the introduction to his book, Scott mentions the contribution of John W. Reps, Department of City and Regional Planning at Cornell University. Reps is an eminent scholar of city planning history. He has taught for many years and also published such works as The Making of Urban America, Cities of the American West, Tidewater Towns, and Monumental Washington. His most recent book, Views and View-makers of Urban America, includes a catalog of all separately published lithographs of towns and cities in the United States from 1825 to 1925 . Reps' books are well documented and most have superior evaluative bibliographies. In contrast to Scott whose research, mentioned above, begins in 1890 and goes through the 1960s, Reps' research concentrates on the period before 1920.

Thomas Mackesey, another long-time faculty member at Cornell, spent many years collecting information for the planning history courses he taught. In 1961 he compiled a bibliography for the Council of Planning Librarians called History of City Planning. Although the book is international in scope, it includes material only up to the Industrial Revolution. Cornell's planning program, founded in 1935, is one of the oldest in the country and has graduated many distinguished professionals. That, along with the dedicated efforts of an outstanding faculty, has enabled

Cornell to assemble the largest archive of papers of planners and planning organizations in the United States. Close to two hundred collections are represented in Cornell's Department of Manuscripts and University Archives. ${ }^{4}$ Computer access to this valuable archive is now available through the Research Libraries Information Network (RLIN).

Several other historians and organizations have contributed to an understanding of planning history. John Hulchanski, professor at the University of Toronto, compiled a bibliography for the Council of Planning Librarians in 1977 titled History of Modern Town Planning, 1800-1940. This bibliography picks up where Mackesey (1961) stops but is not international in scope. It is arranged chronologically by topical headings such as the City Beautiful Movement, 1890-1910, and the City Functional, 1900-1920. Hulchanski concentrates on North America and includes references to both primary and secondary material.

More recently, Martin Gellen of the University of California at Berkeley has added to the historical literature. His annotated bibliography, History of Urban Planning in the U.S. (1983), published by the Council of Planning Librarians, is a selective list dealing with a broad range of urban studies issues including the forces that shape cities, the evolution of local government and politics, cultural influences, public health, education, and social welfare.

Rutgers professor Donald Krueckeberg has edited two new books that have value as reference tools to researchers of the history of the profession. The first is Introduction to Planning History in the U.S. (1983), which is a laudable anthology of recent writings on the subject. The second is The American Planner: Biographies and Recollections (1983), which profiles the major figures in American city planning. The first title was published by the Center for Urban Policy Research at Rutgers, the second by Methuen. Both books have useful indexes 
that enhance their reference value.

The Public Works Historical Society has recently issued an interesting bibliography titled Public Works History in the United States; A Guide to the Literature. Editor Suellen Hoy defines public works as "the basic infrastructure of modern civilization including physical structures and facilities" (1982, p. vii). The book contains chapters on planning administration, engineering, roads, streets, highways, public buildings, parks and recreation, urban mass transit, and energy.

The Planning History Group, founded in England in 1977, has also contributed greatly to the development of historical research. In particular, members Gordon Cherry and Anthony Sutcliffe have published some excellent work. Most notable as a reference source is Sutcliffe's The History of Urban and Regional Planning; An Annotated Bibliography (1981). International in scope, its coverage of the United States is noteworthy. Sutcliffe also includes sections on individual planners and cities. The importance of this book is further enhanced by its clear organization and detailed indexing.

\section{Publications by Professional Planning Organizations}

The profession of city planning is very fortunate in that its major organizations have recognized the value of keeping good records; publishing journals, reports, and books in the field; and providing access to these publications through indexing. The history of American planning organizations begins officially with the National Conference on City Planning in 1909 and continues with the founding of the American City Planning Institute in 1917, which in 1943 became the American Institute of Planners (AIP). The American Society of Planning Officials (ASPO), formed in 1934, merged with the AIP in 1979 to create the American Planning Association (APA). The Urban Land Institute was founded in 1936, and the Council of Planning Librarians was organized in 1958. All of these organizations have been prolific publishers.

The group now known as the American Planning Association began issuing the periodical City Planning in $1925 .{ }^{5}$ It became Planner's Journal in 1935, and in 1944 was renamed Journal of the American Institute of Planners. With the merger of AIP and ASPO in 1979, the name was changed to Journal of the American Planning Association, the current title. ${ }^{6}$ There are two cumulative topical indexes to this periodical. The first covers the first twenty-three volumes published from 1925 through 1958. The more recent covers volumes 24 through 44 (1958-83). ${ }^{7}$ The latter indexes articles by author, title, and subject in one alphabetical listing. In addition, all books reviewed and all book notes in the Journal are listed alphabetically. Author, editor, and reviewer names are listed separately. There are also indexes for correspondence, plan reviews, and editorials. These features provide a very thorough and efficient means of retrieving information published in the profession's premier publication over the last fifty years.

The APA has several other continuing series worth mentioning. Its Planning Advisory Service (PAS) issues two publications. PAS Reports is published eight to ten times a year. Each report covers in depth a single topic of interest to planners. A cumulated index with both chronological and subject access is available for report numbers 1 through 373 and covering the years 1949 to 1982. Since 1982 annual indexes have been included in the December report. The Planning Advisory Service also publishes PAS Memo. Issued monthly and usually thematic, it provides briefer coverage than PAS Reports. An index for the Memos, from the April 1971 inaugural issue to January 1982, appears in the February 1982 issue. The December issues for 1982 through 1985 have included an annual index.

Land Use Law and Zoning Digest is also published by the APA. Begun in 1949 as Zoning 
Digest, it took its current name in 1974. Each monthly issue includes short commentary articles, abstracts of federal and state land-use decisions and recently adopted legislation. An annual index appears in the December issue.

Two other journal publications from the AIP have not survived but are useful for information from the 1970s. They are Planners Notebook, published from 1971-1975, and its continuation, Practicing Planner, issued from 1976-1979. A cumulative index for both titles appears in the last issue of Practicing Planner (June 1979).

One of the early publications begun by ASPO and being continued by the APA started out with the title ASPO Newsletter in 1934, the year ASPO was founded. In 1972 it became ASPO Planning Magazine. After ASPO and the APA merged, the publication was given its current name, Planning. Indexing for this title was sporadic until recently, when a ten year index was issued separately for 1972-1982. Since 1982 an annual index to Planning has appeared in the December issue.

ASPO has provided another invaluable aid to researchers by indexing its annual conference proceedings. In 1962 it issued a cumulative volume called ASPO Index to Proceedings of the National Planning Conferences, 1909-1961 which included not only ASPO meetings from 1934-1961 but also the entire record for the National Conference on City Planning meetings held from 1909 to 1934. The index was edited by Mary Vance, then a librarian at the University of Illinois, who had become interested in the project through the Council of Planning Librarians. The Index lists in one alphabetical arrangement the authors of papers, the subjects discussed, and the geographic locations mentioned. John Worsham later published another cumulation picking up where Vance left off. Interestingly, Worsham's work was published as part of the Public Administration Series of Vance Bibliographies which will be discussed later. Worsham's index is titled Planning, an Author and Subject Index to the Selected Papers from the ASPO National Planning Conferences, 1960-1971. After 1971, publication of the proceedings was suspended. The APA resumed publication in 1981 for one year but at present has no plans to continue.

The Council of Planning Librarians (CPL) has also made a significant contribution to the bibliographies of planning literature. Founded in 1958, this organization has promoted bibliographic inquiry through publication of bibliographies on a broad range of subjects of interest to planners and students of planning. The CPL Exchange Bibliographies series was begun in 1958 by Holway R. Jones, mentioned earlier, then a librarian at the University of California at Berkeley. Jones edited the first thirty-two numbers from 1958 to 1965 and then turned over the editorship to Mary Vance. From 1967 to 1978 she issued a flurry of topical bibliographies (somewhat uneven in quality) in the fields of planning, landscape architecture, urban design, public administration, and architecture from a wide variety of contributors. This first series closed in 1978 when, after eleven years and 1,565 bibliographies, CPL and Vance agreed to part company. During this period Vance had issued indexes at regular intervals — one covering numbers 1-715, another for numbers 716-1193, and the last for numbers 1194-1563. She used the key-word-in-context method for these indexes. A geographic index, compiled by James Starbuck, was also published in nine cumulations from 1958 to 1977, giving geographical access to each applicable entry in all of the over fifteen hundred bibliographies.

In 1978 both Vance and the CPL launched new publishing ventures reminiscent of their earlier collaboration. The Vance Bibliographies look very much like Vance's earlier series but the subject emphasis has shifted. One series of the bibliographies focuses on architecture and now numbers approximately fifteen hundred titles, the other focuses on public administration 
and has approximately two thousand titles. The format of the indexes to these publications has also changed from the original series' key-word-in-context indexing to grouping by title under selected subject terms. Although Vance no longer emphasizes planning, both series still contain many titles useful to planners.

The Council of Planning Librarians has published CPL Bibliographies since 1979, and to date the series containes approximately 160 titles. The bibliographies are topical, consistent in quality, and often provide the researcher with annotations and abstracts. Mary Ravenhall, currently a librarian at the University of Illinois, has prepared a cumulative index for the first 150 titles called An Annotated Bibliography and Index Covering CPL Bibliographies 1-150, January 1979-March 1985. The index is very helpful in evaluating the usefulness of particular titles in the series. The first three numbers of the CPL Bibliographies were devoted to an author, title, and subject index cumulation for the earlier Exchange Bibliographies. Jane Colothakis, compiler of the indexes, used two hundred broad subject terms to group the titles in the earlier series. Though a single cumulation by subject allows for faster searches, researchers still benefit from retaining Vance's earlier key-word-in-context indexing, because it offers more points of access that enhance the likelihood of retrieving appropriate material.

The Urban Land Institute (ULI) has also contributed to the planning information field. Founded in 1936, ULI focuses on the larger developer in an attempt to improve the quality and standards of land use and development. ULI's active publications program provides valuable information in several different series. The longest running title is Urban Land, published continuously since 1941. Monthly issues often focus on a theme in land development such as mixed-use, infill, or recreation. Some subject index cumulations are available for Urban Land, one covering 1965-1969 and another in the December 1980 issue covering 1970-1980. Environmental Comment, another good source of information, was published monthly by ULI from 1973 to 1981. Individual issues were organized around such topics as resource recovery, urban waterfronts, and earth-sheltered development. Either an annual or biennial index was included in most of the December issues.

The Project Reference File (PRF) has been published quarterly by ULI since 1971. PRF capsulizes data on individual development projects in such categories as attached residential, detached residential, commercial, and industrial. These project types are carried over in the annual subject index along with an index by special feature such as adaptive reuse, mixed-use, resort, retail, office condominiums, and PUDs. A geographic index gives access to projects by city and state.

ULI began the Community Builders Handbook series in 1947 with a single volume covering residential and shopping center development. Several revisions later it has become a six volume set outlining development not only of residences and shopping centers but also of offices, industry, downtowns, hotels/motels, and recreation areas.

Development Review and Outlook, published annually by ULI, was initiated in 1983 to provide an overview of various development categories such as offices, residences, and shopping centers in specific development markets and metropolitan areas. Unfortunately, this title was discontinued in 1986.

Concluding ULI's list of series titles is Land Use Digest, issued monthly since 1968. It abstracts important land-use and development information appearing in other publications.

\section{SPECIAL RESEARCH TOOLS}




\section{Catalogs of Library Collections}

When researching topics in city planning, other important sources of information are the library collections available at federal agencies and major schools of planning. The three easiest collections to access are those with printed catalogs. These catalogs are multivolume sets of books that reproduce a library's card catalog. The G. K. Hall Publishing Company is responsible for making all three library catalogs discussed below available in printed form.

The Dictionary Catalog of the U.S. Department of Housing and Urban Development Library and Information Division (1972) covers the original housing library founded in 1934, as well as the collections of the subsequent agencies which culminated in the creation of HUD in 1967. These include the Federal Housing Administration, 1934-37, the Public Housing Administration, 1937-1949, and the Housing and Home Finance Agency, 1949-1966, in addition to the HUD collection. Subject strengths besides housing include community development, urban planning, sociology, architecture, and land use. The initial eighteen volume set covers not only a wide range of books on these subjects but also pamphlets, slides, films, microfiche, and local, state, and federal documents. There is also a complete index of more than twenty thousand comprehensive planning reports generated by Section 701 of the Federal Housing Act of 1954. These reports are indexed geographically and by key word in context. Supplements to the Dictionary Catalog appeared in 1974 (two volumes covering 4,500 books and 4,500 planning reports) and in 1975 (two volumes covering another 4,500 books and 5,500 planning reports).

Although the HUD Library's bibliographic role has been cut back in recent years because of budget constraints, one of its earlier publications deserves mention. Housing and Planning References was first published in 1948 and was issued bimonthly until 1984. Compiled by the library staff, it arranged all the new literature on housing and planning that the library received under preselected subject headings. The entries were frequently annotated and indexes allowed for access by geographic area, author, and key word in context for the 701 Comprehensive Planning Reports listed in each issue. Lack of a cumulative index limits it usefulness, but a great wealth of information can be extracted by those patient enough to wade through each issue by topic.

G. K. Hall has also produced catalogs for two university library collections that reflect both breadth and depth in city planning and related fields. First and foremost is The Dictionary Catalog of the Library of the Graduate School of Design at Harvard University. Since Harvard's program in city planning is the oldest in the nation, its library is particularly comprehensive in areas such as urban design, city and regional planning, state and national planning, housing, zoning, and urban renewal. Its Dictionary Catalog was published in forty-four volumes in 1968. A two volume supplement was produced in 1970, followed by a second supplement of five volumes in 1975. The most recent supplement was issued in three volumes in 1979.

The other collection important to researchers in city planning is in the Avery Architectural Library at Columbia University. Although its primary focus is architecture, The Catalog of the Avery Memorial Architectural Library provides excellent coverage of the roots of the planning profession in the United States as well as of literature on the sociological aspects of urban design and more contemporary material on urban renewal. The first published catalog of the collection appeared in 1895, while the first modern edition was produced in 1958 in six volumes. The nineteen-volume second edition of the Catalog was published in 1968. Supplements have been issued in 1972 (four volumes), 1975 (four volumes), 1977 (three volumes), 1980 (four volumes), and the latest in 1982 (four volumes). Another update is 
promised for 1986.

\section{Indexes and Abstracts}

Reference sources discussed thus far are devoted primarily to information published in book form. But there are many sources that index and abstract periodicals, documents, and reports in the field of city planning. One of the oldest is Public Affairs Information Service Bulletin (PAIS) which began in 1915. The Bulletin is issued biweekly with quarterly and annual cumulations. It offers interdisciplinary coverage of many aspects of public issues and social, economic, and political policy. In addition to scanning over a thousand periodicals, it covers to a lesser degree books, reports, and federal, state, and local documents related to the social sciences. An author index is provided in each annual volume.

Another important publication, launched in 1972, is Index to Current Urban Documents, issued quarterly with annual cumulations by Greenwood Press. The Index lists local government documents for 286 of the largest cities and counties in the United States. Entries are arranged by geographic location, and there is an excellent subject index. Unfortunately, Greenwood depends on the cooperation of public entities in these cities and counties to send in reports to be indexed, resulting in sometimes uneven coverage. However, it is generally an important and unique resource which is well organized and easy to use. The Index also provides access to Greenwood's Urban Documents Microfiche Collection which makes copies of all these documents available on a subscription basis at a cost of approximately $\$ 7,000$ a year.

Greenwood publishes a companion to the Index titled Periodical Literature on United States Cities: A Bibliography and Subject Guide. The first volume, by Barbara Shearer, was issued in 1983 and covered approximately 170 cities with a population of one hundred thousand or more. Articles for the period 1970-1981 are grouped for each city under the topics of architecture, education, media, environment, government, housing and urban development, social and economic conditions, and transportation. The preface promises supplements which would be most welcome, as this work fills the need for a single reference source for access to current information about our cities.

A good publication for abstracts of information pertinent to city planning is Sage Urban Studies Abstracts, which began as a quarterly in 1973. Approximately one thousand books, articles, pamphlets, government documents, dissertations, and research reports are abstracted annually. The emphasis is on scholarly journals and books in urban studies and related social sciences. Entries are arranged in broad subject classes such as urbanism and urbanization, housing, community development and new towns, urban planning and land use, environment and energy, transportation, crime, industry, and urban theory. Because of the breadth of material covered and the use of relatively long abstracts, there is no attempt to be comprehensive. However, the research staff seeks to select the most important new literature. There are annual author and subject indexes but no cumulations, which makes access more difficult. Sage Publications, an offshoot of the Russell Sage Foundation, also publishes Urban Affairs Quarterly, Urban Affairs Annual Reviews, Environment and Behavior, and the Journal of Urban History.

A British publication, international in scope, worth mentioning is GEO Abstracts Part F: Regional and Community Planning. It has been issued bimonthly since 1966. Arrangement is topical, highlighted by such subjects as planning theory and research, statistical techniques, regional and economic planning, architecture and aesthetics, environmental planning, and third 
world development. The abstracts are shorter than Sage's, with about twenty-four hundred a year for books, articles, and reports. Some 550 journals published worldwide are scanned, and the concentration is on theory and practice. Annual indexes are published, and one cumulative index for 1972-76 is available.

The National League of Cities provides perhaps the most timely abstracting source in the weekly Urban Affairs Abstracts begun in 1971. Geared toward practitioners and public agencies rather than academics, each issue scans approximately eight hundred journals dealing primarily with U.S. social, political, economic, technological, and environmental issues. Citations are grouped under some fifty broad subject headings. The abstracts, although not extensive, are very helpful in judging the usefulness of a reference. Since Urban Affairs Abstracts is a weekly publication, its semiannual and annual cumulations and annual authors index are valuable aids to gaining access to its contents.

Even though not published in the United States, Ekistic Index is a useful guide to literature on city planning in this country. Begun in 1968, it is published by the Athens Technological Organization. "Ekistics" is a Greek word coined by Constantine Doxiadis, creator of the Index, to mean the science of human settlements. One hundred fifty U.S. and European journals in the fields of ecology, urban studies, population, architecture, and economics are covered in the Index. Despite some idiosyncracies, the subject coverage of this index is noteworthy and not readily available from other sources.

A recent development in bibliographic surveys of new material in the field is the publication of the Journal of Planning Literature. This journal, published quarterly by the Ohio State University Press, began in the winter of 1986. It offers comprehensive information in the form of review articles and a classified list of recent books and articles, many of which are abstracted.

Indexes and abstracts with a narrower focus or one tangential to planning are also useful. HRIS (Highway Research and Information System) Abstracts has been published by the Transportation Research Board of the National Academy of Science since 1968. Literature abstracted covers all aspects of transportation, traffic, roads, and streets. The abstracts summarize research projects and published work including technical papers, proceedings, and journal articles. This information can be accessed by computer through an on-line database which provides up-to-date information. The printed version, intended to be quarterly, is less effective for current research since it lags about a year in publication.

A title promising to become a valuable reference in the area of land development and planning is Real Estate Periodicals Index, which began in 1981. It indexes approximately thirtyfive real estate and planning journals with entries categorized under four hundred different topical headings. The publisher, John A. Munro Associates of New York City, intended to issue this index quarterly, but so far only annuals have appeared.

References to city planning information continue to appear in the indexes of the disciplines in which city planning is rooted. For instance, Bruce K. Ferguson has compiled the cumulative Index to Landscape Architecture Magazine, 1910-1982. This resource is most useful for historical research, but many current topics of cross-disciplinary interest are also included. Another excellent reference is Art Index, one of the family of H. W. Wilson indexes (e.g., Readers Guide to Periodical Literature, Business Periodicals Index, and Applied Science and Technology Index). It dates back to 1929 and covers two hundred periodicals not only in art and architecture but also in planning and urban design. Finally, in the area of architecture, the Avery Library at Columbia University compiles the Avery Index to Architectural Periodicals. Besides 
the subject of architecture, its thorough indexing of approximately 750 journals worldwide also covers the design aspects of urban planning as well as many other relevant topics. The second edition of the initial fifteen volume set was published in 1972. Indexing is inclusive from 1934 to 1972 with many of the more important titles indexed back to their first volumes in the late 1800s and early 1900s. There have been four supplements since 1973 with the most recent, 1979-82, issued in 1985. While it is definitely not the most current title, when combined with its companion publication, Avery Obituary Index of Architects (2nd edition, 1980), the depth of information on cities, city planning, and city planners is invaluable.

\section{On-Line Databases}

An important development in searching some of the periodical indexes listed above is the availability of on-line computer access. This type of access has several advantages. Terms can be linked through Boolean logic. A greater number of years can be covered in one search, and references are more timely. For example, Research Libraries Group provides access via RLIN (Research Libraries Information Network) to the Avery Index to Architectural Periodicals from 1979 to the present with daily updates. The HUD USER database offers customized annotated bibliographic literature searches; Wilson-line makes Art Index available on-line; PAIS is available through the database vendor DIALOG; and the Information Science Institute (ISI) supplies both its Arts and Humanities and Social Science databases on-line.

\section{Dictionaries and Encyclopedias}

Researchers in city planning often need to refer to encyclopedias or dictionaries for background on particular planning subjects or definitions of planning terms. There are only a few works of this sort specific to planning. The most comprehensive in a historical sense is Arnold Whittick's Encyclopedia of Urban Planning. International in scope, it was published in 1974. The list of distinguished contributors, who have written on all aspects of planning, is impressive. Another notable feature is that the systems of planning legislation and administration in the forty-eight countries where they exist are profiled from their inception to modern times.

Excellent illustrative material including maps, plans, and photographs accompany many entries. Whittick also profiles individual planners who "have contributed something unique, original or distinctive to the art and science of urban planning" (p. xix). He uses an essay format and includes only those who were active prior to 1950. Most entries are signed by their contributors and have bibliographies that make them extremely helpful in locating follow-up information. Definitions of many planning terms are also included.

The more concise Encyclopedia of Planning, compiled by Graham Ashworth, was published in 1973. Less comprehensive than Whittick, this volume defines planning terms and gives brief historical perspectives on some of the more important people and events in the profession. It also provides references for further reading.

Marilyn Spigel Schultz and Vivian Loeb Kasan have collaborated on a more recent work with a decidedly American orientation, the Encyclopedia of Community Planning and Environmental Management (1984). Short entries define terms in land-use regulation, community facility planning, economic development, transportation planning, urban design, housing, social planning, historic preservation, energy conservation, air pollution, solid waste management, and flood control. There are also descriptive entries for important planning 
legislation and articles describing federal agencies in the field. Some illustrations are included, but they are not as prolific as Whittick's.

There are two dictionaries with a somewhat narrower focus on development. One is the Illustrated Book of Development Definitions by Harvey S. Moskowitz, published in 1981 by the Center for Urban Policy Research at Rutgers. The definitions are designed to be used in the appropriate ordinances with little or no change. Each term is accompanied by icons that quickly identify it as applicable to the broad categories of zoning, subdivision, site planning, and environment. Robert J. Dumouchel's Dictionary of Development Terminology: The Technical Language of Builders, Lenders, Architects and Planners (1975), though older, is still valuable because it deals more broadly with housing and urban renewal than the Moskowitz book.

Two dictionary format references on the city are worth noting. One was compiled by Charles Abrams, who, during his academic career at Columbia University, collected material for his Language of Cities; A Glossary of Terms Dealing with Housing, City Planning and Associated Disciplines. It was published posthumously in 1971, and even though much has happened in the field in the past fifteen years, Abrams's definitions are classics and still useful for his insights.

The City, a Dictionary of Quotable Thought on Cities and Urban Life was compiled by James Clapp in 1984. It is a subjective but fascinating collection of verses, quotes, lyrics, proverbs, and scriptures, all with themes relating to cities. Some of the references are taken from standard sources like Bartletfs Familiar Quotations and the Oxford Dictionary of Quotations, but most were collected by Clapp through research he conducted over a period of years first as a student and later as a faculty member. The book is arranged by the names of persons quoted, and there are indexes for the subjects and the cities covered. The book is an excellent source of epigrammatic material for articles and speeches.

\section{SPECIAL TOPIC AREAS}

\section{Cities}

Finding infomation on cities is often challenging. Two good sources, mentioned earlier, are Index to Current Urban Documents and Periodical Literature on United States Cities. Sutcliffe's History of Urban and Regional Planning also has a section devoted to historical planning references for major cities worldwide. Neil Shumsky, a professor at Virginia Polytechnic Institute, has compiled a bibliography titled Urban America; A Historical Bibliography listing all of the material in the index, America: History and Life, volumes 11 to 17 (1974-80), related to urban areas. This involves four thousand abstracts of articles and books.

For general background on the urban phenomenon there are two useful titles. One is Dwight Hoover's bibliography, Cities (1976). There are approximately one thousand annotated entries covering both print and nonprint media organized under topics such as housing, transportation, ethnic groups, urban planning, architecture, urban history, government, and economics. Author and title indexes are also included. Although published earlier, Charles Bryfogle's The City in Print; A Bibliography (1973) is more comprehensive including almost twice as many annotated references for print and audio-visual items than Hoover. Bryfogle also gives a number rating from one to four for each title to indicate its appropriateness.

Bibliographic studies have been published for some major U.S. cities. For instance, Perry Fisher of the Columbia Historical Society has compiled Materials for the Study of Washington, 
D.C. (1974). There is a bibliographic guide to New York City written by Manuel Lopez titled New York: A Guide to Information and Reference Sources (1980). The Chicago Historical Society has published Frank Jewell's Annotated Bibliography of Chicago History (1979). And, as an outgrowth of the Los Angeles Metropolitan History Project, there is a huge tome titled Los Angeles and its Environs in the Twentieth Century; A Bibliography of a Metropolis (1973).

A good source for information on land development in major U.S. cities is the meeting brochure published by ULI for the locations of their semiannual meetings. To date these separately produced publications have profiled approximately twenty cities giving extensive information on both commercial and residential development projects.

\section{Housing}

Reference works are also available for the popular research topic of housing. Many of the works cited earlier have sections devoted to certain aspects of housing, but separately published, all-inclusive bibliographies are not plentiful or current. The most recent is by John Rouse, Urban Housing, Public and Private; A Guide to Information Sources (1978) in the Gale Research Urban Studies Information Guide Series mentioned earlier. Virginia Paulus earlier compiled a work which is especially thorough for the decade of the 1960s titled Housing: A Bibliography, 1960-1972 (1974). Paulus refers to an even earlier publication by William Wheaton, Housing, Renewal and Development Bibliography, published in 1968, which she recommends for pre1960 references. For a complete historical perspective on housing in the United States, some of the best resources are the bibliographic essays that accompany each chapter of Gwendolyn Wright's Building the Dream; A Social History of Housing in America (1981). Wright not only provides excellent chronological coverage of housing references but also critically selects the most worthwhile references from the available body of literature.

Besides the journal literature covered in PAIS and other general indexes, information on housing is available from the Department of Housing and Urban Development, Office of Policy Development and Research which has published Compendium of Research Reports semiannually since 1979. Though its future is in doubt, this is a good source for abstracts of research dealing with a wide variety of housing issues.

\section{Historic Preservation}

Historic preservation has been a subject of increased interest in the past decade. It has had a significant impact on urban design and planning, as the Tax Reform Act of 1976 has made renovating and reusing existing buildings economically more attractive. ${ }^{8}$

Early references to the preservation movement are covered thoroughly in Frederick Rath's series which began in 1966 with the first comprehensive bibliography in the field. Called the Selective Reference Guide to Historic Preservation, it was published by the New York State Historical Association. In 1970 Rath published an expanded edition titled Guide to Historic Preservation, Historical Agencies, and Museum Practices: A Selective Bibliography. In 1975 the information was expanded into a three volume set, each volume covering one of the topics in the 1970 edition's title. This set was produced by Rath and Merrilyn O'Connell under the title $A$ Bibliography of Historical Organization Practices. The first volume, Historic Preservation, deals with broad issues in preservation law, urban development and redevelopment, preservation research and planning, and preservation action. Each entry under these topics has a useful 
annotation.

Another early reference to the literature of preservation was published in 1969 by Gary Menges, then a librarian at Cornell University. His CPL Exchange Bibliography \#79, Historic Preservation; A Bibliography, cites over eight hundred books and articles drawn from the collections of the Cornell Libraries. The scope of the material is international, but Menges focuses on the United States with state-by-state listings of case studies and surveys.

In 1975, Richard Tubesing published Architectural Preservation in the U.S., 1965-1974 (CPL Exchange Bibliography \#812-813). It was expanded in 1978 and released by Garland Publishing Co. with the title Architectural Preservation in the United States, 1941-1975; A Bibliography of Federal, State and Local Government Publications. In 1982 Garland published another of Tubesing's books - Architectural Preservation and Urban Renovation; An Annotated Bibliography of U.S. Congressional Documents.

Federal agencies such as the Advisory Council on Historic Preservation (ACHP), an independent governmental body, have also contributed to the reference literature. In 1982 ACHP published Where to Look; A Guide to Preservation Literature. Oriented toward local preservation organizations and practitioners, this guide supplies references for identifying and recording cultural resources, protective strategies, preserving and restoring structural fabric, publicity, and training and educational programs.

Another federal agency, the U.S. Department of Interior's National Park Service, responsible for federal review of historic properties, has also issued several helpful bibliographies. Two of these are Historic Preservation Bibliography, its second edition having been compiled by Robert Haynes in 1979, and Rehabilitation of Historic Buildings; An Annotated Bibliography by Frederick Kleyle (1980).

The most recent comprehensive bibliography in the preservation field was published by Gale Research Company in 1980 using the format of the Urban Information Guide Series mentioned earlier. Historic Preservation: A Guide to Information Sources, however, is part of Gale's Art and Architecture Information Guide Series. The author, Arnold Markowitz, a reference librarian at New York University, has compiled numerous references, most of them annotated, under such topics as historical and current overviews; international sources; financial, legal and planning aspects; description and documentation; materials and techniques; and renovation, restoration, and reuse. Excellent indexing by subject, author, title, and organization is also provided.

The most prolific publisher of preservation-related literature is the National Trust for Historic Preservation, a nonprofit group organized in 1946. The Trust's Preservation Press, headed by Diane Maddex, has issued many important reference sources. An early title, compiled by Ann Baggerman in 1976, is Historic Preservation Plans; An Annotated Bibliography, which lists plans for districts, cities, regions, states, open spaces, and waterfronts. Another Preservation Press title, The Brown Book; A Directory of Preservation Information, was edited by Diane Maddex and released in 1983. It is a potpourri of facts, addresses, definitions, and lists of contacts along with other miscellaneous but useful information. Maddex's most recent effort, All About Old Buildings; A Whole Preservation Catalog, takes the Brown Book a step further. Published in 1985, it is the result often years of collecting information about all facets of the preservation field.

Preservation Press has also put together several organizational listings useful to the researcher who needs to contact preservation groups. Two of these are Directory of Private, Nonprofit Preservation Organizations: State \& Local Levels (1980) and Directory of American 
Preservation Commissions (1981).

In the area of documentation, Jean Travers, a National Trust intern in 1978, compiled Guide to Resources Used in Historic Preservation Research, which provides basic information on preservation documentation.

Finally, a new title published in cooperation with the National Trust by Adler and Adler promises to be an outstanding annual addition to the literature of preservation. This is The Historic Preservation Yearbook; A Documentary Record of Significant Policy Developments and Issues. Edited by Russell Keune, a former vice-president at the Trust, the Yearbook first appeared in 1985. Highlights include government involvement in preservation, financing techniques, and preservation policy disputes and their resolution.

\section{CONCLUSIONS}

The current state of reference sources in the field of city planning evidences some positive developments and gives rise to some cause for concern. It is gratifying to see planning history get more bibliographic attention. The formation of the Planning History Group in Great Britain and the more recent founding of the American City Planning History Society at the first National Conference held on the subject in Columbus, Ohio, March 1986, should enhance efforts to bring even more attention to control of the literature in this area.

The expanding availability of computerized databases brings the hope that in the near future electronic bibliographic control will provide researchers in city planning with faster and more thorough access to information. The resumption of the Avery Index to Architectural Periodicals and the commitment to keep it on a regular schedule along with the introduction of the Journal of Planning Literature will add increased timeliness as well as greater coverage for the discipline.

Funding - or rather, lack of it - is the major cause for concern for the future of publications in this field. Many of the comprehensive bibliographies mentioned in this article are now fifteen or more years old and in need of updating. It is increasingly difficult to finance such publications because they do not generate a sufficient audience to make them commercially viable without charging an astronomical price for them. This leaves nonprofit groups' publishing programs especially vulnerable. Many groups also have not been able to publish new editions of handbooks or directories in the past six to ten years. This has also contributed to the current uncertainty about continuation of the Council of Planning Librarians publishing programs. (Although, at this writing, it appears that the American Planning Association will assume management of the CPL Bibliographies series.) Loss of federal money for research efforts from the Department of Housing and Urban Development level down to the individual investigator threatens to decrease opportunities for publishing quality comprehensive reference sources. Creative solutions to these financial concerns will have to be found to allow development of reference material for the next generation of researchers.

\section{NOTES}

1. For more information on Hubbard's contribution to the profession, see Eugenie Ladner Birch, "From Civic Worker to City Planner: Women and Planning, 1890-1980," in The American Planner; Biographies and Recollections, ed. Donald Krueckeberg (New York: Methuen, 1983).

2. For more information on later classification schemes, see Arthur Comey and Katherine McNamara, State and National Planning; An Analysis of the Subject Arranged with Particular Reference to the 
Classification of Library Material (Cambridge, Ma.: Harvard University Press, 1937). Caroline Shillaber, the librarian who later followed McNamara at Harvard, published a revised list titled A Library Classification for City and Regional Planning (Cambridge, Ma.: Harvard University Press, 1973). Shillaber refers to her work as "a revision of Pray and Kimball's city planning classification of 1913." Cf. Pray and Kimball (1913).

3. For a history of planning organizations through 1979, see Eugenie Ladner Birch, "Advancing the Art and Science of Planning: Planners and Their Organizations, 1909-1980," Journal of the American Planning Association 46, 1: 22-49 (1980).

4. For more information on the Cornell collections, see Urban America: Documenting the Planners, a catalogue of an exhibition at the John M. Olin Library, Cornell University, October 21-December 31, 1985, on the occasion of the 50th anniverary of the Department of City and Regional Planning.

5. The journal preceding City Planning was called The City Plan. It was published by The National Conference on City Planning from 1915-1918.

6. For more information on the evolution of this professional journal, see Donald Krueckeberg, "The Story of the Planner's Journal, 1915-1980,"/owrwfl/ of the American Planning Association 46, 1: 5-21 (1980).

7. Interim indexes covering three to four years were done over the fifty year period but are no longer necessary since the twenty-five year cumulations supersede them.

8. For a review of current literature on preservation, see James N. Carder's "In the Balance" column titled "American Historic Preservation," Choice (April 1983).

\section{REFERENCES}

Abrams, Charles. 1971. The language of cities; A glossary of terms dealing with housing, city planning and associated disciplines. New York: Viking Press.

Advisory Council on Historic Preservation. 1982. Where to look; A guide to preservation literature. Washington, D.C.: Advisory Council on Historic Preservation.

Alexander, Ernest R., Anthony Catanese, and David S. Sawicki. 1979. Urban planning: A guide to information sources (Urban Studies Information Guide Series, Volume 2). Detroit: Gale Research Co.

American Planning Association. Planning Advisory Service. 1971- . PAS Memo. Chicago: American Planning Association. 1949- . PAS Reports. Chicago: American Planning Association.

Applied Science and Technology Index. 1913- . Bronx, N.Y.: H. W. Wilson Co.

Art Index. 1929- . Bronx, N.Y.: H. W. Wilson Co.

Ashworth, Graham. 1973. Encyclopedia of planning. London: Barrie \& Jenkins.

ASPO Newsletter. 1934-71. Chicago: American Society of Planning Officials.

ASPO Planning Magazine. 1972-78. Chicago: American Society of Planning Officials.

Baggerman, Ann, comp. 1976. Historic preservation plans; An annotated bibliography. Washington, D.C.: Preservation Press.

Bestor, George C, and Holway R. Jones. 1972. City planning bibliography; A basic bibliography of sources and trends. New York: American Society of Civil Engineers.

Black, Russell VanNest. 1967. Planning and the planning profession: The past fifty years, 1917-1967. Washington, D.C.: American Institute of Planners.

Branch, Melville C. 1970. Comprehensive urban planning; A selective annotated bibliography with related materials. Beverly Hills: Sage Publications.

Bryfogle, R. Charles. 1973. The city in print; A bibliography. Agincourt, Ont.: General Learning Press.

Business Periodicals Index. 1958- . Bronx, N.Y.: H. W. Wilson Co.

Chapin, F. Stuart, Jr. 1978. Selected references on urban planning concepts and methods. Chapel Hill, N.C.: Department of City and Regional Planning, University of North Carolina.

Clapp, James. 1984. The city, a dictionary of quotable thought on cities and urban life. New Brunswick, N.J.: Rutgers University, Center for Urban Policy Research.

Columbia University. Avery Architecture Library. 1980. Avery obituary index of architects. Second edition. Boston: G. K. Hall.

1972. Avery index to architectural periodicals. Second edition. 15 volumes. Supplements published in 1975 (for 1973-74), 1977 (for 1975-76), 1979 (for 1977-78), and 1985 (for 1979-82). Boston: G. K. Hall. 1968. The Catalog of the Avery Memorial Architectural Library. Second edition. 19 volumes. Supplements 
published in 1972 (4 vols.), 1975 (4 vols.), 1977 (3 vols.), 1980 (3 vols.), and 1982 (4 vols.). Boston: G. K. Hall.

Community Builders Handbook Series:

Downtown development handbook. 1980. Washington, D.C.: Urban Land Institute.

Industrial development handbook. 1975. Washington, D.C.: Urban Land Institute.

Office development handbook. 1982. Washington, D.C.: Urban Land Institute.

Recreational development handbook. 1981. Washington, D.C.: Urban Land Institute.

Residential development handbook. 1978. Washington, D.C.: Urban Land Institute.

Shopping center development handbook. 1985. Washington, D.C.: Urban Land Institute.

Council of Planning Librarians. 1979- . CPL Bibliographies. Chicago: Council of Planning Librarians.

Council of Planning Librarians. 1958-1978. Exchange bibliographies \#1-1565. Mary Vance, ed. Monticello, II.:

Council of Planning Librarians.

Development Review and Outlook. 1983-84 and 1984-85. Washington, D.C.: Urban Land Institute.

Dumouchel, J. Robert. 1975. Dictionary of development terminology: The technical language of builders, lenders, architects and planners. New York: McGraw-Hill.

Ekistic Index. 1968- . Athens, Greece: Athens Center of Ekistics.

Environment \& Behavior. 1969- . Beverly Hills, Ca.: Sage Publications.

Environmental Comment. 1973-1981. Washington, D.C.: Urban Land Institute.

Ferguson, Bruce K. 1983. Index to landscape architecture magazine, 1910-1982. Mesa, Az.: PDA Publishers.

Fisher, Perry. 1974. Materials for the study of Washington, D.C: A selected annotated bibliography. Washington, D.C: George Washington University.

Gellen, Martin. 1983. History of urban planning in the U.S.: An annotated bibliography. (CPL Bibliographies \#109.) Chicago: Council of Planning Librarians.

Geo Abstracts Part F: Regional and Community Planning. 1966- . Norwich, England: Geo Abstracts.

Harvard University. Graduate School of Design. Frances Loeb Library. 1968. Dictionary catalog of the library of the Graduate School of Design. 44 volumes. Supplements published in 1970 (2 vols.), 1975 (5 vols.), and 1979 (3 vols.). Boston: G. K. Hall.

Haynes, Robert. 1979. Historic preservation bibliography. Second revised edition. Washington, D.C: Department of the Interior, Heritage Conservation and Recreation Service.

Hoover, Dwight. 1976. Cities. New York: Bowker.

Housing and Planning References. 1948-1984. Washington, D.C: U.S. Department of Housing and Urban Development, Library and Information Division.

Hoy, Suellen, ed. 1982. Public works history in the United States: A guide to the literature. Nashville, Tn.: American Association for State and Local History.

HRIS Abstracts. 1968- . Washington, D.C: Transportation Research Board, National Academy of Science.

Hubbard, Theodora Kimball, and Katherine McNa-mara. 1928. Planning information up-to-date, a supplement, 1923-1928. Cambridge, Ma.: Harvard University Press.

Hulchanski, John David. 1977. History of modern town planning, 1800-1940; A bibliography. (Exchange Bibliography \#1239). Monticello, II.: Council of Planning Librarians.

Index to Current Urban Documents. 1972- . Westport, Ct.: Greenwood Press.

Jewell, Frank. 1979. Annotated bibliography of Chicago history. Chicago: Chicago Historical Society.

Journal of Planning Literature. 1986- . Columbus, Oh.: Ohio State University Press.

Journal of the American Institute of Planners. 1944-1978. Cambridge, Ma.: American Institute of Planners.

Journal of the American Planning Association. 1979- . Chicago: American Planning Association.

Journal of Urban History. 1974- . Beverly Hills, Ca.: Sage Publications.

Keune, Russell, ed. 1985. The historic preservation yearbook; A documentary record of significant policy developments and issues. Bethesda, Md.: Adler \& Adler.

Kimball, Theodora. 1923. Manual of information on city planning and zoning, including references on regional, rural, and national planning. Cambridge, Ma.: Harvard University Press.

Kimball, Theodora. 1915. Classified selected list of references on city planning. Boston: National Conference on City Planning.

Kleyle, Frederick, ed. 1980. Rehabilitation of historic buildings; An annotated bibliography. Washington, D.C: U.S. Department of the Interior, Heritage Conservation and Recreation Service.

Krueckeberg, Donald, ed. 1983. The American planner: Biographies and recollections. New York: Methuen. , ed. 1983. Introduction to planning history in the U.S. New Brunswick, N.J.: Center for Urban Policy Research. 
Land Use Digest. 1968- . Washington, D.C.: Urban Land Institute.

Land Use Law and Zoning Digest. 1949- . Chicago: American Planning Association.

Lopez, Manuel D. 1980. New York; A guide to information and reference sources. Metuchen, N.J.: Scarecrow Press.

Los Angeles Metropolitan History Project. 1973. Los Angeles and its environs in the twentieth century; A bibliography of a metropolis. Los Angeles: Ward Ritchie Press.

Mackesey, Thomas. 1961. History of city planning. (Exchange Bibliography \#19). Monticello, II.: Council of Planning Librarians.

McNamara, Katherine. 1936. Bibliography of planning, 1928-1935; A supplement to manual of planning information, 1928. Cambridge, Ma.: Harvard University Press.

Maddex, Diane, ed. 1985. All about old buildings; A whole preservation catalog. Washington, D.C.: Preservation Press. ed. 1983. The brown book; A dictionary of preservation information. Washington, D.C.: Preservation Press.

Markowitz, Arnold. 1980. Historic preservation: A guide to information sources. Detroit: Gale Research Co.

Menges, Gary. 1969. Historic preservation; A bibliography. (Exchange Bibliography \#79). Monticello, II.: Council of Planning Librarians.

Moskowitz, Harvey S. 1981. The illustrated book of development definitions. New Brunswick, N.J.: Center for Urban Policy Research.

National Trust for Historic Preservation. 1981. Directory of American preservation commissions. Washington, D.C.: Preservation Press. 1980. Directory of private non-profit preservation organizations: State and local levels. Washington, D.C.: Preservation Press.

Paulus, Virginia. 1974. Housing: A bibliography, 1960-1972. New York: AMS Press. Planner's Journal. 19351943. Boston: American City Planning Institute.

Planners Notebook. 1971-1975. Washington, D.C.: American Institute of Planners.

Planning. 1979- . Chicago: American Planning Association.

Practicing Planner. 1976-1979. Washington, D.C.: American Institute of Planners.

Pray, James Sturgis, and Theodora Kimball. 1913. City planning; A comprehensive analysis of the subject arranged for the classification of books, plans, photographs, notes and other material. Cambridge, Ma.: Harvard University Press.

Project Reference File. 1971- . Washington, D.C.: Urban Land Institute.

Public Affairs Information Service. 1915- . Bulletin. New York: Public Affairs Information Service.

Rath, Frederick. 1970. Guide to historic preservation, historical agencies, and museum practices: A selective bibliography. Cooperstown, N.Y: New York Historical Association. 1966. Selective reference guide to historic preservation. Cooperstown, N.Y: New York State Historical Association.

Rath, Frederick, and Merrilyn O'Connell. 1975. A bibliography of historical organization practices, Volume 1 : Historic preservation. Nashville, Tn.: American Association for State and Local History.

Readers Guide to Periodical Literature. 1900- . Bronx, N.Y: H. W. Wilson Co.

Real Estate Periodicals Index. 1981- . New York: John A. Munro Associates.

Rouse, John. 1978. Urban housing, public and private: A guide to information sources (Urban Studies Information Guide Series). Detroit: Gale Research Co.

Sage Urban Studies Abstracts. 1973- . Beverly Hills, Ca.: Sage Publications.

Schultz, Marilyn Spigel, and Vivian Loeb Kasan. 1984. Encyclopedia of community planning and environmental management. New York: Facts on File.

Scott, Mel. 1969. American city planning since 1890: A history commemorating the fiftieth anniversary of the American Institute of Planners. Berkeley: University of California.

Shearer, Barbara. 1983. Periodical literature on United States cities; A bibliography and subject guide. Westport, Ct.: Greenwood Press.

Shumsky, Neil, ed. 1983. Urban America: A historical bibliography. Santa Barbara, Ca.: ABC-Clio Information Services.

Spielvogel, Samuel. 1951. A selected bibliography on city and regional planning. Washington, D.C.: Scarecrow Press.

Sutcliffe, Anthony. 1981. The history of urban and regional planning; An annotated bibliography. New York: Facts on File.

Travers, Jean. 1978. Guide to resources used in historic preservation research. Washington, D.C.: Preservation Press. 
Tubesing, Richard. 1982. Architectural preservation and urban renovation; An annotated bibliography of U.S. congressional documents. New York: Garland. .1982. Architectural preservation in the United States, 1941 -1975; A bibliography of federal, state and local government publications. New York: Garland. . 1975. Architectural preservation in the U.S., 1965-1974. (Exchange Bibliography \#812-813). Monticello, II.: Council of Planning Librarians.

United States Department of Housing and Urban Development. Library and Information Division. 1972. The dictionary catalog of the U.S. Department of Housing and Urban Development Library and Information Division, Washington, D.C. 18 volumes. Supplements published in 1974 (2 vols.) and 1975 (2 vols.). Boston: G. K. Hall.

United States Department of Housing and Urban Development. Office of Policy Development and Research. 1979- . Compendium of research reports. Germantown, Md.: HUD USER.

Urban Affairs Abstracts. 1971- . Washington, D.C.: National League of Cities.

Urban Affairs Annual Reviews. 1967- . Beverly Hills, Ca.: Sage Publications.

Urban Affairs Quarterly. 1965- . Beverly Hills, Ca.: Sage Publications.

Urban Land. 1941- . Washington, D.C.: Urban Land Institute.

Vance, Mary, ed. 1978- . Vance bibliographies. Architecture Series, \#1- . Public Administration Series, \#1- . Monticello, II.: Vance Bibliographies. 1962. ASPO index to proceedings of the national planning conferences, 1909-1961. Chicago: American Society of Planning Officials.

Wheaton, William. Housing, renewal and development bibliography. (Exchange Bibliography \#46). Monti-cello, II.: Council of Planning Librarians.

Whittick, Arnold, ed. 1974. Encyclopedia of urban planning. New York: McGraw-Hill.

Worsham, John. 1979. Planning, an author and subject index to the selected papers from the ASPO national planning conferences, 1960-71. (Public Administration Series \#297). Monticello, II.: Vance Bibliographies.

Wright, Gwendolyn. 1981. Building the dream; A social history of housing in America. New York: Pantheon Books. 